[一般論文/Transaction】

\title{
ジクロロイソシアヌル酸を用いる綿セルロース布の TEMPO 触媒酸化
}

\author{
田中 千晶*1 $\cdot$ 由井 美也*1 ・磯貝 明*2,\# \\ *1グンゼ株式会社研究開発部(京都) \\ *2東京大学大学院農学生命科学研究科
}

\section{TEMPO-Mediated Oxidation of Cotton Cellulose Fabrics with Sodium Dichloroisocyanurate}

\author{
Chiaki Tanaka*1, Yoshinari Yui ${ }^{* 1}$, and Akira Isogai ${ }^{* 2, \#}$ \\ ${ }^{*} 1$ Gunze Limited, 1 Ishiburo, Inokurashin-machi, Ayabe, Kyoto 623-8512, Japan \\ ${ }^{*}$ Graduate School of Agriculture and Life Science, The University of Tokyo, \\ 1-1-1 Yayoi, Bunkyo-ku, Tokyo 113-8567, Japan
}

\begin{abstract}
Cotton fabrics were oxidized with sodium dichloroisocyanurate (SDIC) and catalytic amounts of 2,2,6,6-tetramethylpiperidin-1-oxyl (TEMPO) and $\mathrm{NaBr}$ in water at $\mathrm{pH} 9$ or 10 and temperatures of $15-40{ }^{\circ} \mathrm{C}$ for 5-15 min. The TEMPO-oxidized fabrics were post-treated with $\mathrm{NaClO}_{2}, \mathrm{H}_{2} \mathrm{O}_{2}$ and $\mathrm{NaBH}_{4}$. The oxidized cotton fabrics thus obtained had higher carboxylate contents and higher viscosity-average degrees of polymerization (DP $v$ ), compared with the conventional TEMPO/ $\mathrm{NaBr} / \mathrm{NaClO}$ or $\mathrm{TEMPO} / \mathrm{NaClO} / \mathrm{NaClO}_{2}$ system when the oxidation was carried out under similar conditions. Because SDIC gradually releases $\mathrm{HOCl}$ in water, forming $\mathrm{NaOCl}$ at $\mathrm{pH} \mathrm{10}$, this $\mathrm{NaClO}$ is preferentially consumed for oxidation of C6-primary hydroxyl groups of cellulose, rather than cellulose depolymerization or formation of $\mathrm{C} 2 / \mathrm{C} 3$ ketones. As a result, the decrease in whiteness of the oxidized cotton fabrics without post $\mathrm{NaBH}_{4}$ treatment after heating was lower than those prepared with TEMPO/NaBr/NaClO system. Moreover, the TEMPO/NaBr/SDIC oxidation of cotton fabrics can be carried out in water at $\mathrm{pH} 9$, which leads to the same carboxylate content as that prepared in water at pH 10 but higher $\mathrm{DP}_{\mathrm{v}}$. Thus, the TEMPO/NaBr/SDIC is an efficient and promising system for oxidation of cotton fabrics with high carboxylate contents and high $\mathrm{DP}_{\mathrm{v}}$ values, suitable for functionalization of cotton fabrics for clothes and underwear.
\end{abstract}

(Received 29 April, 2016; Accepted 8 June, 2016)

\section{1. 緒 言}

綿セルロースは衣料素材として, ニットや織物等の 繊維構造物として多岐にわたり利用されている。これ まで, 綿セルロースに新機能を付与するために, 化学 修飾や表面改質, 薬剤塗布等による高機能化の研究が 数多く報告されている[1-3]. しかし，新たな機能を 有しながら, 従来の衣料材料としての強度, 柔軟性, 加熱変色耐性, 洗濯耐久性等の基本物性を維持する手 法の開発は困難である．新たな衣料素材としての利用 拡大のためには, 本来の綿セルロースの基本物性を維 持可能な, 温和な化学改質一機能付与方法の開発が求 められている.

一方, 水系媒体でのセルロースの位置選択的かつ効
率的な化学改質方法として TEMPO $(2,2,6,6$ - テトラメ チルピベジニル - 1-オキシルラジカル)による触媒酸 化反応が注目されている。 TEMPO と $\mathrm{NaBr}$ を触媒と して添加し, 主酸化剂である次亜塩素酸ナトリウム $(\mathrm{NaClO})$ 水溶液を用いる常温常圧での TEMPO/ $\mathrm{NaBr}$ $/ \mathrm{NaClO}$ 系反応により, 水溶性多糖の 1 級水酸基をほ ほ全てカルボキシ基に酸化可能であることが 1995 年 に報告された [4]．この TEMPO 触媒酸化を木材セル ロース(製紙用漂白クラフトパルプ)に適用した場合に は，セルロースの結晶性ミクロフィブリル構造を維持 したまま，その表面に高密度で規則的にカルボキシ基 を導入できる $[5,6]$.

そこで, 衣料用綿セルロースの温和な改質一機能化 を目的とし, 綿布への TEMPO 触媒酸化反応条件と,

\# corresponding author : 
酸化綿布の構造および特性解析等が検討されてきた [7-10]。共触媒である $\mathrm{NaBr}$ を $\mathrm{Na}_{2} \mathrm{SO}_{4}$ に代替した $\mathrm{TEMPO} / \mathrm{Na}_{2} \mathrm{SO}_{4} / \mathrm{NaClO}$ 系酸化反応でも, 綿布の改 質に十分な量のカルボキシ基を導入可能で，なおから 重合度低下や加熱処理による白色度低下を制御するこ とができた $[8]$. また, 約 $0.3 \mathrm{mmol} / \mathrm{g}$ 以上のカルボキ シ基を導入した TEMPO 酸化綿布はアンモニアや酢 酸に対して明暸な消臭機能を示した[8]. さらに, $\mathrm{Na}_{2} \mathrm{SO}_{4}$ を用いる酸化反応系では, 綿セルロース繊維 断面方向に偏りなく, 均一にカルボキシ基が導入され ることが見いだされた[9]。そこで，TEMPO/ $\mathrm{Na}_{2} \mathrm{SO}_{4}$ / $\mathrm{NaClO}$ 酸化系に打ける, 酸化型TEMPO分子 ( $\mathrm{TEMPO}^{+}$あるいは $N$-オキソアンモニウム塩)の生成 と反応性, 安定性等を, 電子スピン共鳴装置を用いて 検討した[9].

一方, $\mathrm{pH} 10$ での TEMPO 触媒酸化反応では, 主 酸化剂である $\mathrm{NaClO}$ 添加による綿セルロースの重合 度低下が避けられない[9]。綿セルロースの重合度低 下は, 綿布の剛度の増加, 風合いの低下の要因となる。 そこで, 重合度低下を制御可能な, 中性〜弱酸性水溶 液中での綿布の $\mathrm{TEMPO} / \mathrm{NaClO} / \mathrm{NaClO}_{2}$ 系酸化条件 と, 酸化綿布の構造および特性を検討した $[10]$ 。この 中性系 TEMPO 触媒酸化反応によってセルロースの 重合度低下, 加熱後の白色度低下をある程度制御する ことができた．しかし， $40 \sim 90^{\circ} \mathrm{C}$ への加温，長時間 の反応時間, 反応装置の密閉化等が必要となり, 実用 化には課題があった[10].

そこで, 本研究では TEMPO 触媒酸化反応過程で のセルロースの重合度低下を制御することを目的とし， $\mathrm{NaClO}$ の代替としてジクロロイソシアヌル酸ナトリ ウム(図 1) (sodium dichloroisocyanurate: SDIC と省 略)を検討した. SDIC は水に溶解すると, 徐々に次 亜塩素酸を生成する $[11,12] . \mathrm{NaClO}$ 水溶液はアルカ リ性であるが, SDIC は水に溶解しても中性であり， 塩素失活がほとんどなく安定である $[11,12]$. そこで, SDIC を使用することで反応初期に $\mathrm{NaClO}$ を一度に 添加することによるセルロース綿布の重合度低下，そ れによる綿布の脆化を防ぎ，加えて適正量のカルボキ シ基を綿布に導入する酸化反応条件を検討した.

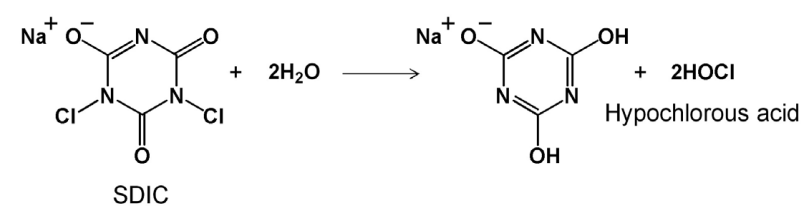

Fig. 1 Chemical structure of sodium dichloroisocyanurate (SDIC) and formation of hypochlorous acid from SDIC in water.

\section{2. 実 験}

\section{1 試料}

綿布試料は, 糸番手 $40 / 1\left(\mathrm{DP}_{\mathrm{v}}=2200\right)$ のニット構造 物(フライス綿布)を使用した。ニット生地編立時の機 械油や綿布自身が含有する不純物を除去するため, 非 イオン性の界面活性剤 (三洋化成工業社製グランアッ プ RS-5000) $1 \mathrm{~g} / \mathrm{L}$ 濃度, 炭酸ナトリウム $5 \mathrm{~g} / \mathrm{L}$ 濃度の 水溶液中で $70^{\circ} \mathrm{C}, 20$ 分処理後, 湯洗浄-水洗し, $40^{\circ} \mathrm{C}$ で 2 時間処理して含水率を $3 \%$ 程度まで低下させたの ち, $20^{\circ} \mathrm{C}, 65 \%$ 相対湿度 $(\mathrm{RH})$ で 24 時間調湿した [8-10]．調湿後の含水率は約 7\% であった. TEMPO および各種ニトロキシルラジカル, 酸化剤等, その他 の試薬抒よび溶媒類は, 市販の試薬特級品をそのまま 使用した。

\subsection{TEMPO 触媒酸化}

TEMPO $2.0 \mathrm{~g}$ と NaBr $14.0 \mathrm{~g}$ をイオン交換水 $2.4 \mathrm{~L} に$ 添加し，摚汼して溶解させた．続いて未漂白綿布 $80 \mathrm{~g}$ を投入し, 十分綿布を反応溶液に浸透, 浸漬させた. 続いて擋汼下に, 所定量の SDIC あるいは $\mathrm{NaClO}$ 水 溶液を加え, 所定の $\mathrm{pH}$ に希 $\mathrm{NaOH}$ 水溶液あるいは 希 $\mathrm{HCl}$ 水溶液を添加して調整し, 酸化反応を開始し た. 所定の反応時間処理後, 反応溶液から酸化綿布を 取り出し, イオン交換水にて, 常温で十分洗浄後, 遠 心脱水機(染色堅牢度洗濯試験機: スガ試験機侏社製 LM-12D) を用い, 含水率約 $100 \%$ まで脱水した。

\subsection{TEMPO 酸化綿布の追酸化処理}

上記 TEMPO 触媒酸化処理によりC6 位の一部は カルボキシ基に酸化されるが, 少量の C 6 -アルデヒ ド基が生成する $[5,6]$. そこで, $1.6 \mathrm{~L} の$ 蒸留水に, $25 \mathrm{wt} \%$ の $\mathrm{NaClO}_{2}$ 水溶液 $216 \mathrm{~g}$ を加えた後, 2.2 項で 調製した未乾燥の TEMPO 酸化綿布を投入, 浸漬さ せ，テクサム技研社製 $12 \mathrm{EL}$ ミニカラー染色機を用い て, $\mathrm{pH} 4,80^{\circ} \mathrm{C}$ で 60 分間追酸化処理した(対綿布絶 乾重量当たり $4 \%$ の $\mathrm{NaClO}_{2}$ を使用)。この追酸化処 理により酸化綿布中に生成した微量 C6-アルデヒド 基を C6-カルボキシ基に酸化した[13]. その後, 加 熱イオン交換水に浸漬して湯洗い, 室温イオン交換水 に浸漬して十分に水洗し, 2.2 項に従って脱水した.

\subsection{TEMPO 酸化綿布の脱 $\mathrm{NaClO}_{2}$ 処理}

2.3 項で得られた $\mathrm{NaClO}_{2}$ で追酸化した TEMPO 酸 化綿布中に微量残存する $\mathrm{NaClO}_{2}$ を分解一除去するた め[8-10], 下記の処理を扔こなった. 2.4Lのイオン 交換水に, $35 \mathrm{wt} \% \mathrm{H}_{2} \mathrm{O}_{2}$ 水溶液とポリカルボン酸系キ レート剤(日華化学社製ネオレートPLC 7000)を $0.96 \mathrm{~g}$ 添加して擋拌後, $1.0 \mathrm{M} \mathrm{NaOH}$ 水溶液にて $\mathrm{pH} 10.6$ に 調整した？その溶液に未乾燥の $\mathrm{NaClO}_{2}$ 追酸化 TEMPO 酸化後綿布を投入して十分擋找させた後,

再度 $1.0 \mathrm{M} \mathrm{NaOH}$ 水溶液にて pH 10.6 に調整し, 2.3 項と同装置にて, $70^{\circ} \mathrm{C}, 20$ 分処理した。 その後, 処 
理綿布を熱水イオン交換水中に浸漬して湯洗い後, 室 温のイオン交換水中に浸漬-水洗し, 2.2 項に従って 脱水した.

\subsection{TEMPO 酸化綿布の還元処理}

TEMPO 酸化反応により, C $2 / \mathrm{C} 3$ 位に微量生成し たケトン基を水素化ホウ素ナトリウム $\left(\mathrm{NaBH}_{4}\right)$ で還元 処理した. $4.0 \mathrm{~L}$ のイオン交換水に $4.0 \mathrm{~g}$ の $\mathrm{NaBH}_{4}$ を 溶解させ (この段階で溶液の $\mathrm{pH}$ は 11 以上), 2.4 項ま でに調製した $\mathrm{H}_{2} \mathrm{O}_{2}-\mathrm{NaClO}_{2}$ 処理した TEMPO 酸化綿 布を投入後，希塩酸を用いて $\mathrm{pH} 10$ に調整した。続 いて 2.3 項と同装置にて, $25^{\circ} \mathrm{C}, 20$ 分追還元処理した 後, $1.0 \mathrm{M} \mathrm{HCl}$ 水溶液を添加して生地を含んだまま反 応液を中和し, $\mathrm{NaBH}_{4}$ を分解した。 その後, $\mathrm{NaBH}_{4}$ $\mathrm{H}_{2} \mathrm{O}_{2}-\mathrm{NaClO}_{2}$ 処理した TEMPO 酸化綿布をイオン交 換水中に浸漬して十分洗浄後, 脱水し, $40^{\circ} \mathrm{C}$ で 2 時 間乾燥した。

\subsection{TEMPO 酸化綿布の分析}

TEMPO 酸化綿布中のカルボキシ基量は電導度滴 定装置(平沼産業株式会社製 COM-1600) を用い，既報 に従って測定した [8-10]．重合度は2.5 項で還元処理 した各種 TEMPO 酸化綿布を $0.5 \mathrm{M}$ 銅エチレンジア ミン水溶液に溶解させ, キャピラリー粘度法により既 法に従って極限粘度を求め, 重合度の值に変換した [8-10].

\section{7 加熱による白色度低下測定}

$\mathrm{NaBH}_{4}$ 処理前後の酸化綿布を予め $20^{\circ} \mathrm{C} ， 65 \% \mathrm{RH}$ で 3 時間調湿し, 白色度を分光光度計 (Kollmorgen Instruments 社製 WHITE-EYE 3000)を用い, D65 光 源 $2^{\circ}$ 視野で測定し, CIE $L^{*} a^{*} b^{*}$ 表色系で下式により 白色度を算出した。

$$
\text { 白色度 }(\%)=L^{*}-3 b^{*}
$$

その後, 酸化綿布を $105^{\circ} \mathrm{C}$ で 2 時間加熱処理し, $20^{\circ} \mathrm{C}$, $65 \%$ RH で 7 時間調湿して白色度を上記と同じ方法で 測定し，白色度低下を次式により算出した：白色度低 下 $(\%)=[$ 加熱前の白色度 $)-($ 加熱処理後の白色度 $)]$ $\div$ (加熱前の白色度 $) \times 100[8-10]$.

\section{8 酸化綿布の剛軟性評価}

TEMPO 酸化綿布をイオン交換水にて浸漬し，マ ングルを用いて均一に圧搾してピンテンターで乾燥し た。この綿布試料 $20 \times 20 \mathrm{~cm}^{2}$ を $20^{\circ} \mathrm{C} ， 65 \% \mathrm{RH}$ で 24 時間調湿し，ハンドロメーター(Handle-O-Meter)を 用いて測定した(JIS L-1096E 法) [8].

\section{3. 結果と考察}

\subsection{TEMPO/NaBr/SDIC 反応系酸化処理}

SDIC を主酸化剤とし，その添加量を変えて綿布に 対して $\mathrm{pH}$ 10, 室温 10 分の処理条件で TEMPO 触媒 酸化を行った．対照実験として，従来の $\mathrm{NaClO}$ を主 酸化剤として綿布に対する TEMPO 触媒酸化を行っ

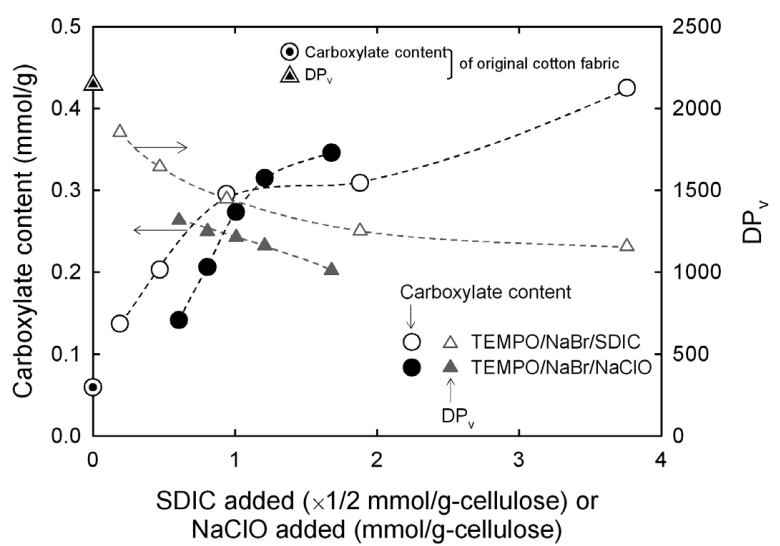

Fig. 2 Carboxylate content and $\mathrm{DP}_{\mathrm{v}}$ of the original cotton fabric and TEMPO-oxidized cotton fabrics prepared by TEMPO/NaBr/SDIC or TEMPO/ $\mathrm{NaBr} / \mathrm{NaClO}$ system with various SDIC or $\mathrm{NaClO}$ addition levels in water at $\mathrm{pH}$ 10 and room temperature for $10 \mathrm{~min}$.

た. 全ての TEMPO 酸化綿布試料は, 2.3〜2.5 項で示 す $\mathrm{NaClO}_{2}$ 追酸化- $\mathrm{H}_{2} \mathrm{O}_{2}$ 処理- $\mathrm{NaBH}_{4}$ 追還元処理を行い, 導入されたカルボキシ基量と重合度を比較した．両酸 化反応における主酸化剤の添加量に対する, TEMPO 酸化綿布のカルボキシ基量と重合度の関係を図 2 に示 す.なお， 1 モルの SDIC 添加量は, 図 1 に示すよう に 2 モル分の $\mathrm{HClO}$ 添加量に対応するため, 図 2 の横 軸はSDIC の添加モル量の $1 / 2$ で示す.

図 2 の横軸の值が $1 \mathrm{mmol} / \mathrm{g}$ 以下の領域では, 主酸 化剂として SDIC を用いた場合は, $\mathrm{NaClO}$ を用いる 場合よりも, 同一添加量で比較した場合に, 酸化綿布 に導入されたカルボキシ基量が増加し，重合度低下を 抑えることができた，両酸化反応系ともに $\mathrm{pH} 10$ で 行っているので, 中間体として生成するC6-アルデ ヒド基が $\mathrm{pH} 10$ の条件下で $\beta$ 脱離反応によって生じ る分子量低下は，両反応系で差があるとは考えにくい， SDIC系の場合には，添加したSDIC が徐々に $\mathrm{HClO}$ を放出し, $\mathrm{NaClO}$ に変換されてセルロース綿布中の C6 位の 1 級水酸基を酸化する $[11,12]$. 一方, $\mathrm{NaClO}$ 系の場合には, 全量を一度に反応液に加えるため, $\mathrm{NaClO}$ による $\mathrm{OH}$ ラジカル等の活性副生成物濃度が 高くなり, 結果的にセルロースのグルコシド結合の開 裂による分子量低下の要因になったと推測される [14] したがって TEMPO/NaBr/SDIC 系においては, 添 加した SDIC が綿布のカルボキシ基生成に優先的に消 費され，七ルロースの重合度低下に消費される量が $\mathrm{NaClO}$ 系に比べて少ないことが明らかになった。

\section{2 熱処理による白色度低下}

$\mathrm{TEMPO} / \mathrm{NaBr} / \mathrm{NaClO}$ 系で酸化処理し,さらに $\mathrm{NaClO}_{2}$ 追酸化しても $\mathrm{NaBH}_{4}$ 追還元処理しない酸化綿 布は，熱処理によって黄変することが報告されている [8-10]. TEMPO 触媒酸化反応はセルロースのC6 位の 1 級水酸基を選択的に酸化する。 しかし， C $2 / \mathrm{C}$ 
3 位も微量酸化されてケトン基が副生するため, それ らが熱処理によって黄変する原因となる $[15]$ ．した がって，加熱処理による白色度低下を低減するには酸 化綿布中に微量副生した $\mathrm{C} 2 / \mathrm{C} 3$ ケトン基を, $\mathrm{NaBH}_{4}$ を用いて還元する必要がある [16].

そこで, TEMPO $/ \mathrm{NaBr} / \mathrm{SDIC}$ 系と TEMPO $/ \mathrm{NaBr}$ $/ \mathrm{NaClO}$ 系処理で得られた酸化綿布について, 加熱処 理による黄変化一白色度低下の程度を測定した，両酸 化綿布を $\mathrm{NaClO}_{2}$ で追酸化し， $\mathrm{NaBH}_{4}$ による還元処理 の有無による，酸化綿布中のカルボキシ基量に対する， 熱処理後の白色度低下を図 3 に示す。なお，熱処理前 の酸化綿布の白色度は 88～92\% であった. $\mathrm{NaBH}_{4}$ よ る追還元処理のない酸化綿布の白色度低下については, 両反応系とも生成したカルボキシ基量の増加に伴い, 白色度低下が増加した。しかし, 白色度低下の程度は TEMPO $/ \mathrm{NaBr} / \mathrm{NaClO}$ 系の方が大きくなった。この 結果から, 酸化反応初期に $\mathrm{NaClO}$ の全量を添加する $\mathrm{TEMPO} / \mathrm{NaBr} / \mathrm{NaClO}$ 系では，セルロースのC 6 位 の 1 級水酸基の酸化反応に加え, $\mathrm{C} 2 / \mathrm{C} 3$ 位のケトン 基への酸化の程度も，大きいことを示している.すな わち, 図 2 の結果と同様, $\mathrm{HClO}$ を除放する SDIC の 方が重合度低下， C $2 / \mathrm{C} 3$ 位のケトン基への酸化に消 費される量が $\mathrm{NaClO}$ よりも少ないと考えられる.

一方, $\mathrm{NaBH}_{4}$ による追還元処理後は, 両酸化綿布 間での白色度低下の差は少なくなった。この結果から も, $\mathrm{NaBH}_{4}$ による追還元処理前の白色度低下が, 酸 化綿布中に副生する微量の $\mathrm{C} 2 / \mathrm{C} 3$ ケトン基に由来す

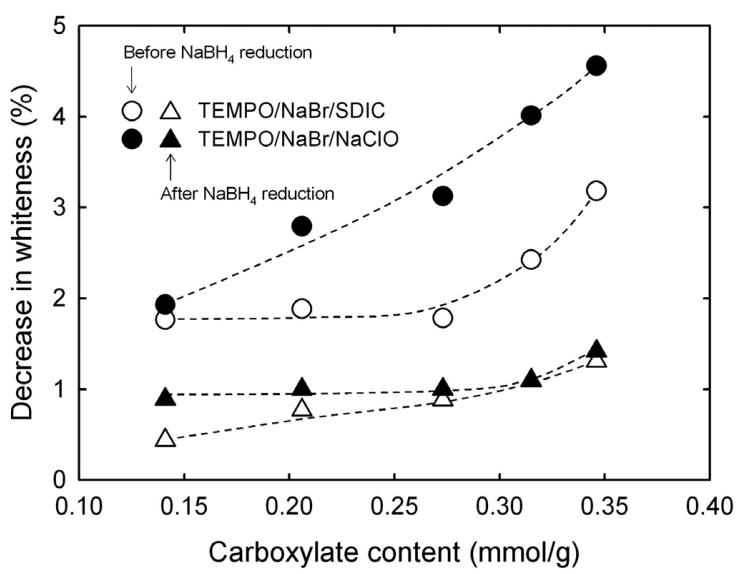

Fig. 3 Decrease in whiteness of TEMPO-oxidized cotton fabrics with or without $\mathrm{NaBH}_{4}$ reduction after heating at $105^{\circ} \mathrm{C}$ for $2 \mathrm{~h}$.
ると考えらえる. $\mathrm{NaBH}_{4}$ による追還元処理後でも， 酸化綿布中には加熱処理による白色度低下の要因とな る構造あるいは物質が含まれてはいるが, 加熱処理に よる白色度低下が $1.5 \%$ 以下であることは，十分に実 用化可能な值と言える.

$\mathrm{NaBH}_{4}$ による追還元処理は弱アルカリ性条件で反 応が効率的に進むため $[16], \mathrm{NaClO}_{2}$ 処理後の脱 $\mathrm{NaClO}_{2}$ 処理である弱アルカリ性下での $\mathrm{H}_{2} \mathrm{O}_{2}$ 処理後, 綿布の単離一洗浄処理が不要でそのまま同浴(ワン ポット)での還元処理の可能を検討した. すなわち, $\mathrm{NaBH}_{4}$ 処理を, 酸化綿布を単離一洗浄後に行った場合 と, $\mathrm{H}_{2} \mathrm{O}_{2}$ 処理に続けてワンポットで行った場合の, 酸化綿布の加熱処理による白色度低下と, 剛軟度への 影響を測定した(表 1)。両酸化綿布共にカルボキシ量 は $0.33 \mathrm{mmol} / \mathrm{g}$ に統一した.

$\mathrm{NaBH}_{4}$ による追還元処理を同浴処理で行った場合 と, 別浴処理で行った場合で, 加熱処理による綿布の 白色度低下には大きな差異がなかった。したがって， 同浴処理でも酸化綿布中に存在する微量ケトン基を同 程度還元可能である。一方, 綿布の剛軟度は同浴処理 の方が優れていた．この原因としては，別浴処理と同 浴処理での綿布の洗浄回数の差が影響していると考え られる.すなわち, 別浴処理では 3 回分洗浄工程が多 くなる. $\mathrm{NaBH}_{4}$ による追還元処理は, 弱アルカリ性 で行うため, 還元処理後の残存 $\mathrm{NaBH}_{4}$ の分解と反応 液の中和の際に多量の酸を添加する。 その際の反応一 洗浄液の $\mathrm{pH}$ の繰り返し変化が，七ルロースの膨潤収 縮処理の繰り返し履歴となり, 重合度低下や繊維の フィブリル化が進行し, 綿布の剛度が高くなったと推 察する.

\section{3 酸化反応温度・反応時間の影響}

図 2 の結果から, TEMPO/ $\mathrm{NaBr} / \mathrm{SDIC}$ 系では室温 条件, 10 分の反応時間で, TEMPO/ $\mathrm{NaBr} / \mathrm{NaClO}$ 系 よりも重合度低下を抑えながら, 高いカルボキシ基生 成量となった，そこで本項では, TEMPO/ $\mathrm{NaBr} / \mathrm{SDIC}$ 系に打いて, 反応温度 $15 \sim 40^{\circ} \mathrm{C}$, 反応時間 $5 \sim 15$ 分 の酸化条件に対する, 酸化綿布のカルボキシ基量, 重 合度を検討した(図 4). 本項の実験では, $\mathrm{H}_{2} \mathrm{O}_{2}$ 処理 に続く $\mathrm{NaBH}_{4}$ による追還元処理は，前項の結果に基 づいて全て同浴で行った。試験した酸化綿布試料の, 還元処理後の加熱処理による白色度低下は $0.6 \%$ 程度

Table 1 The effect of $\mathrm{NaBH}_{4}$-treatment method to TEMPO-oxidized cotton fabrics on their whiteness values and bending resistances.

\begin{tabular}{|c|c|c|c|c|}
\hline \multirow{2}{*}{ Treatment } & \multicolumn{2}{|c|}{ Whiteness (\%) } & \multirow{2}{*}{$\begin{array}{c}\text { Decrease in } \\
\text { whiteness after } \\
\text { heating }\end{array}$} & \multirow{2}{*}{ Bending resistance } \\
\hline & Before heating & After heating & & \\
\hline $\begin{array}{l}\text { Separate } \mathrm{H}_{2} \mathrm{O}_{2} \text { and } \\
\mathrm{NaBH}_{4} \text { treatments }\end{array}$ & 90.9 & 89.9 & 1.0 & 54 \\
\hline $\begin{array}{l}\text { One pot } \mathrm{H}_{2} \mathrm{O}_{2}-\mathrm{NaBH}_{4} \\
\text { treatment }\end{array}$ & 90.7 & 89.8 & 0.9 & 43 \\
\hline
\end{tabular}




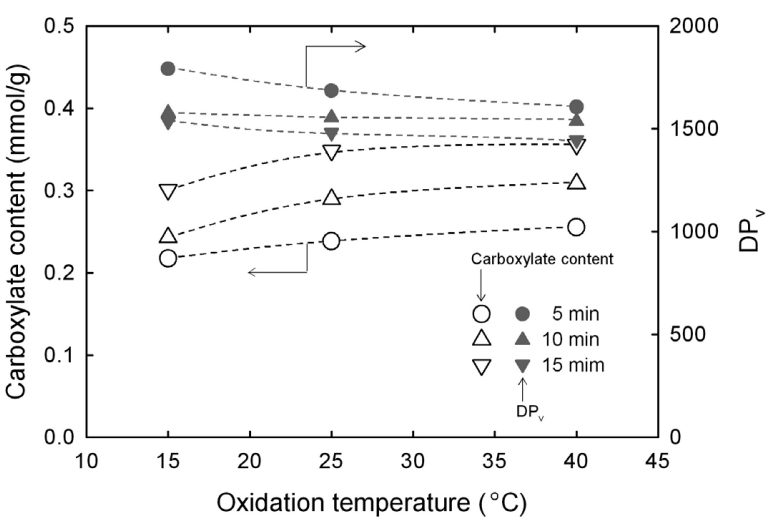

Fig. 4 Carboxylate content and $\mathrm{DP}_{\mathrm{v}}$ of oxidized cotton fabrics prepared with TEMPO/NaBr/ SDIC system in water at $\mathrm{pH} 10$ under conditions of various temperatures and oxidation times.

で一定であった，図 4 の結果から, 反応温度, 反応時 間を制御することにより，酸化綿布中のカルボキシ基 量，重合度をある程度制御できることが明らかになっ た.

続いて, 図 4 で得られた結果を, 酸化綿布のカルボ キシ基量と重合度の関係で示し, 対照としてこれまで 報告した $\mathrm{pH} 10$ の TEMPO/ $\mathrm{NaBr} / \mathrm{NaClO}$ 系, $\mathrm{pH} 3.8$ あるいは $\mathrm{pH} 6.8$ の TEMPO $/ \mathrm{NaClO} / \mathrm{NaClO}_{2}$ 系あるい は 4-AcNH-TEMPO / $\mathrm{NaClO} / \mathrm{NaClO}_{2}$ 系 (4-AcNHTEMPO:4-アセトアミド TEMPO)の結果も合わせ て示す(図 5).

図 5 に示すように, TEMPO/NaBr/SDIC 系酸化で は, カルボキシ基量の増加に伴い重合度が低下する傾 向を示した。しかし，これまで報告してきた他の TEMPO 触媒酸化反応で調製した酸化綿布に比べて, 同一カルボキシ基量で明瞭に高い重合度となった。特 に, カルボキシ基量 $0.35 \mathrm{mmol} / \mathrm{g}$ 付近では, 高重合度 の酸化綿布が得られた。

したがって, 反応温度 $40^{\circ} \mathrm{C}$, 反応時間 15 分という 過酷な酸化条件でも，HOCl の徐放性により SDIC が カルボキシ基の生成に優先的に消費され，重合度低下 に消費される量が少ないと推察できる，セルロース中 の $\mathrm{C} 6$ 位の 1 級水酸基のカルボキシ基への酸化には必 ず中間体として C6-アルデヒド基の生成を経ている. それにもかかわらず，SDIC 系では高重合度の酸化綿 布が得られたことから, 酸化綿布中のセルロースの分 子量低下には，C6-アルデヒド基に由来する $\beta$ 脱離 反応だけではなく, $\mathrm{NaClO}$ から TEMPO 酸化反応条 件で副生する例えば $\mathrm{OH}$ ラジカルが関与していると考 えられる $[14]$

\section{4 酸化反応浴の $\mathrm{pH}$ の影響}

$\mathrm{NaClO}$ 水溶液は, 水酸化ナトリウム水溶液に塩素 ガスを溶解させて製造されるためにアルカリ性である のに対し, SDIC は水に溶解しても中性を示す. $\mathrm{TEMPO} / \mathrm{NaBr} / \mathrm{NaClO}$ 系によるセルロースの酸化反

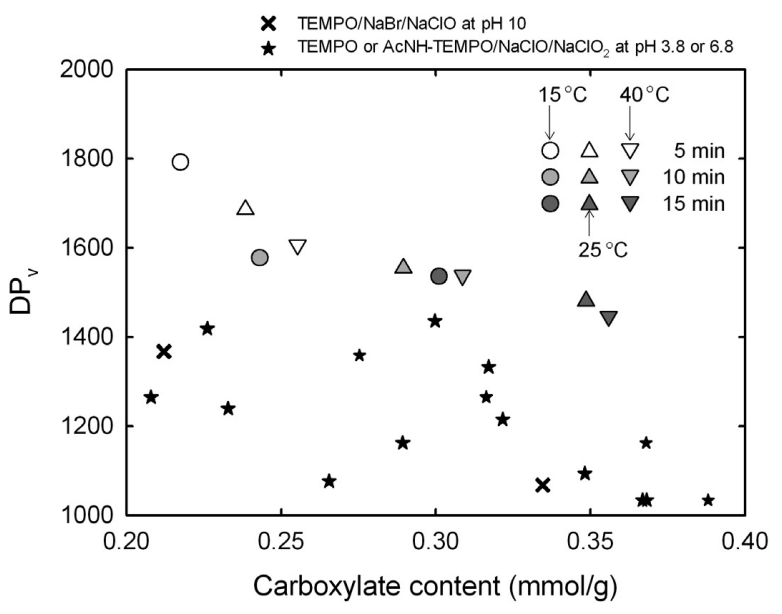

Fig. 5 Relationships between carboxylate content and $\mathrm{DP}_{\mathrm{v}}$ of oxidized cotton fabrics prepared by TEMPO/NaBr/SDIC at pH 10, TEMPO/ $\mathrm{NaBr} / \mathrm{NaClO}$ at $\mathrm{pH} 10$, TEMPO/NaClO/ $\mathrm{NaClO}_{2}$ and 4-AcNH-TEMPO/NaClO/ $\mathrm{NaClO}_{2}$ at $\mathrm{pH} 3.8$ or 6.8 [8-10].

応では, 反応浴の $\mathrm{pH}$ は 10 が最適(高カルボキシ基量 を与える)と報告されている $[5,6]$. 一方, SDIC 水溶 液は中性で, 水溶液中で $\mathrm{HClO}$ を徐放するため, 従来 より低い $\mathrm{pH}$ で綿布の酸化反応を行うことができる可 能性がある。 そこで, 室温, 10 分の反応条件で, 反 応浴の $\mathrm{pH}$ を変化させて酸化綿布を調製し, $\mathrm{NaClO}_{2}$ $\mathrm{H}_{2} \mathrm{O}_{2}-\mathrm{NaBH}_{4}$ 処理後のカルボキシ基量と重合度を測定 した(図6).

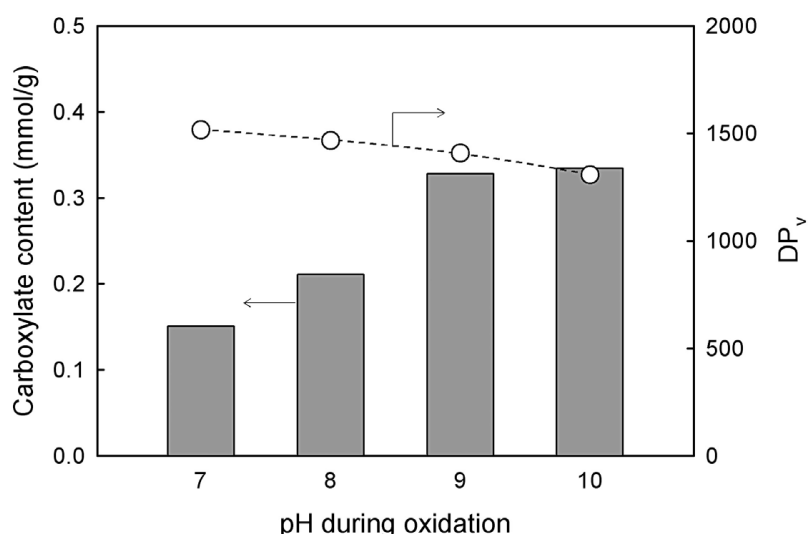

Fig. 6 Carboxylate content and $\mathrm{DP}_{\mathrm{v}}$ of oxidized cotton fabrics prepared with TEMPO/NaBr/ SDIC system in water at $\mathrm{pH} \mathrm{7-10} \mathrm{and} \mathrm{room}$ temperature for $10 \mathrm{~min}$.

酸化綿布のカルボキシ基量は $\mathrm{pH}$ の増加に対応して 増加した。しかし pH 9 と 10 では, 酸化綿布のカル ボキシ基量は同等であった。一方，重合度は $\mathrm{pH} 10$ では 1310 に対し, pH 9 では 1410 と高い值となった。 TEMPO 触媒酸化反応で，セルロース中に中間体と して生成する C6-アルデヒド基はアルカリ性条件下 での $\beta$ 脱離反応による低分子化の 1 要因でもあり [10], $\mathrm{pH}$ を 9 に下げること,すなわち， $\mathrm{OH}^{-}$イオン 濃度を $1 / 10$ に下げることができれば，対応して $\beta$ 脱 
Table 2 The effect of TEMPO derivatives in catalytic oxidation of cotton fabrics with SDIC in water at $\mathrm{pH} 10$ and room temperature for 10 min on carboxylate content and $\mathrm{DP}_{\mathrm{v}}$ of the post $\mathrm{NaClO}_{2}-\mathrm{H}_{2} \mathrm{O}_{2}-\mathrm{NaBH}_{4}$-treated fabrics and whiteness values of the fabric samples with and without $\mathrm{NaBH}_{4}$ treatment after heating at $105^{\circ} \mathrm{C}$ for $2 \mathrm{~h}$.

\begin{tabular}{lcccc}
\hline TEMPO derivatives & $\begin{array}{c}\text { Carboxylate content } \\
(\mathrm{mmol} / \mathrm{g})\end{array}$ & $\mathrm{DP}_{\mathrm{v}}$ & $\begin{array}{c}\text { Decrease in whiteness of } \\
\mathrm{NaBH}_{4} \text {-treated sample } \\
\text { after heating (\%) }\end{array}$ & $\begin{array}{c}\text { Decrease in whiteness of } \\
\text { non } \mathrm{NaBH}_{4} \text {-treated } \\
\text { sample after heating (\%) }\end{array}$ \\
\hline TEMPO & 0.334 & 1310 & 1.1 & 2.2 \\
4-AcNH-TEMPO & 0.331 & 1240 & 1.6 & 2.3 \\
4-MeO-TEMPO & 0.343 & 1330 & 1.4 & 2.6 \\
AZADO & 0.260 & 604 & 2.2 & 9.3 \\
\hline
\end{tabular}

離反応によるセルロースの低分子化を抑えることがで きる. 図 6 の結果から, 綿布の TEMPO/NaBr/SDIC 系酸化では，反応浴の $\mathrm{pH}$ を 9 に設定可能であると判 断した.

\section{5 酸化反応における TEMPO 誘導体類の影響}

前項までの結果から, 綿布の TEMPO 触媒酸化反 応でSDICを主酸化剤として用いることが, $\mathrm{NaClO}$ を主酸化㓮とする反応系や中性〜弱アルカリ性の $\mathrm{NaClO}_{2}$ を主酸化剂とする反応系よりも，カルボキシ 基の導入効率，重合度低下の制御の観点から優れてい ることが判明した，そこで本項では，綿布の酸化触媒 として, TEMPO, 4-AcNH-TEMPO, 4-メトキシ TEMPO (4-MeO-TEMPO), 2 - アザアダマンタン $-N-$ オキシル (AZADO) 間での酸化効果を検討した.

反応条件は 3.4 項と同じく, pH 10 で室温, 10 分間 に設定した，TEMPO，4-AcNH-TEMPO，4-MeOTEMPO の添加量は対綿布絶乾重量に対して 0.16 $\mathrm{mml} / \mathrm{g}$ に設定し, 酸化触媒効率が高い[17]AZADO のみ $1 / 10$ の添加量の $0.016 \mathrm{mmol} / \mathrm{g}$ とした. $\mathrm{NaClO}_{2}$ $\mathrm{H}_{2} \mathrm{O}_{2} \mathrm{NaBH}_{4}$ 処理を経た酸化綿布のカルボキシ基量, 重合度, および $\mathrm{NaBH}_{4}$ 処理前後での, 加熱処理後の 白色度低下度の結果を表 2 に示す．僅かな差異ではあ る が, TEMPO, 4-AcNH-TEMPO, 4-MeO-TEMPO 間では, 導入カルボキシ基量, 重合度の観点から，4MeO-TEMPO が優れていた，AZADOを用いた場合 には，導入カルボキシ基量も少なく，特に重合度の低 下が顕著であり, 本綿布の酸化には不適当である.

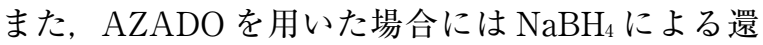
元処理前の加熱処理による白色度低下が著しく, C2/ C3 位のケトン基への酸化が, 他の触媒よりも進むこ とが推察された $[17]$.この $\mathrm{C} 2 / \mathrm{C} 3$ ケトン基の生成量 の増加が, pH 10 での酸化反応中のセルロース重合度 の低下原因となっていると考えられる．したがって， 表 2 の結果は, 4-MeO-TEMPO/NaBr/SDIC 系の反応 が綿布の酸化に適していることを示す.

\section{4. 結 論}

綿布の温和な化学改質を目的とし，従来の $\mathrm{pH} 10$ での $\mathrm{TEMPO} / \mathrm{NaBr} / \mathrm{NaClO}$ 系, 中性〜弱酸性系での $\mathrm{TEMPO} / \mathrm{NaClO} / \mathrm{NaClO}_{2}$ 系に対し, 安定な固体で水 に溶解すると中性で $\mathrm{HOCl}$ を除放する特性を有する SDIC を主酸化剤とする弱アルカリ性での TEMPO/ $\mathrm{NaBr} / \mathrm{SDIC}$ 系酸化を検討した. その結果, 同じ酸化 条件であれば， $\mathrm{NaClO}$ を主酸化剂とする酸化反応よ りも, 高カルボキシ基量で, 高重合度の酸化綿布が得 られた. 同じカルボキシ基量の酸化綿布で比較すると, 中性〜弱酸性条件での TEMPO/ $\mathrm{NaClO} / \mathrm{NaClO}_{2}$ 系よ りも高重合度となった，これらの結果は，徐放性のあ るSDICを用いることにより，この主酸化郕がセル ロース中の $\mathrm{C} 6$ 位の 1 級水酸基の酸化に優先的に消費 され，重合度低下への寄与が少ないことを示している。 さらに, $\mathrm{NaClO}_{2}$ による追酸化処理後の弱アルカリ性 条件での $\mathrm{H}_{2} \mathrm{O}_{2}$ 処理に続き, 同浴で $\mathrm{NaBH}_{4}$ による追還 元処理することにより，洗浄工程が削減でき，その結 果酸化綿布の剛軟度も向上させることができた．また， 反応温度 $40^{\circ} \mathrm{C}$ 条件でも重合度低下を抑えながら 0.3 $\mathrm{mmol} / \mathrm{g}$ 以上のカルボキシ基量が導入可能になった. 加えて, 反応浴を $\mathrm{pH} 9$ とすることも可能であり, 対 応して酸化綿布の重合度低下を制御できた，TEMPO 誘導体類の中では, 酸化綿布のカルボキシ基量と重合 度の観点から 4-MeO-TEMPO が優れていた。

\section{文 献}

1. M. Masuda, K. Shiozawa, "Sen-i Kako Gijutsu", Chijin Shokan, Tokyo, p. 156 (1989).

2. Y. Yanai, "Encyclopedia of Cellulose", Ed. by Japan Cellulose Society, Asakura Shoten, Tokyo, p. 502 (2000).

3. The 120 Committee for Fiber and Polymer Processing, "Senshoku Kinou Kakou”, Japan 
Society for The Promotion of Science, Tokyo, p. 313 (2004).

4. A. E. de Nooy, A. C. Besemer, H. Bekkum, Carbohydr. Res., 269, 89 (1995).

5. T. Saito, S. Kimura, Y. Nishiyama, A. Isogai, Biomacro-molecules, 8, 2485 (2007).

6. A. Isogai, T. Saito, H. Fukuzumi, Nanoscale, 3, 71 (2011)

7. Y. Cho, A. Suzuki, E. Hasegawa, M. Miyamoto, M. Ishi, G. Meshitsuka, Sen 'i Gakkaishi, 65, 146 (2009).

8. Y. Yui, C. Tanaka, A. Isogai, Sen'i Gakkaishi, 69, 222 (2013).

9. Y. Yui, C. Tanaka, A. Isogai, Sen'i Gakkaishi, 70, 53 (2014).
10. C. Tanaka, Y. Yui, A. Isogai, Sen'i Gakkaishi, 71, 191 (2015).

11. Y. Kato, A. Horiguchi, M. Hayashi, A. Yabe, $J$. Home Econ. Japan, 20(1), 46 (1969).

12. M. Hayashi, J. Japan Res. Assoc. Text. End-Uses, 15, 271 (1974).

13. R. Shinoda, T. Saito, Y. Okita, A. Isogai, Biomacromolecules, 13, 842 (2012).

14. I. Shibata, A. Isogai, Cellulose, 10, 151-158 (2003).

15. M. Takahashi, J. Jpn. Soc. Colour Materi., 52(7), 380 (1979).

16. S. Takaichi, T. Saito, R. Tanaka, A. Isogai, Cellulose, 21, 4093-4103 (2014).

17. S. Takaichi, A. Isogai, Cellulose, 20, 1979-1988 (2013). 